\title{
FACTORS AFFECTING STUDENTS CHOOSING MANAGEMENT STUDY PROGRAM (CASE STUDY ON THE FACULTY OF ECONOMICS AND BUSINESS, Dr. SOETOMO UNIVERSITY, SURABAYA)
}

\author{
Sandra Oktaviana Pinaraswati ${ }^{1}$, Saibat $^{2}$ \\ ${ }^{1,2}$ Universitas Dr. Soetomo Surabaya \\ Email: Sandra.oktaviana@unitomo.ac.id
}

Abstract: $\quad$ The purpose of this study was to examine and analyze: The factors that influence students in choosing a Management study program at Dr. Soetomo University, Surabaya. This research is motivated by a fairly tight competition between private universities in Surabaya to attract students who will continue their studies at higher education, and the large number of study program choices. To win the competition, each private university tries to improve the quality of its study program with various strategies. On the other hand, students have many choices to decide what study program, and which private university to choose. There are certain study programs and private universities that are very popular, and some are less attractive. Therefore, it is very important that the student decision-making process in choosing a study program in a particular private university is analyzed through a study of consumer behavior. Data analysis used is quantitative, while to analyze quantitative data using multiple linear regression analysis. The results showed the $R$ Square coefficient of 0.682 means that variations in student decisions can be explained by the cultural, social, personality, and psychological variables of $68.2 \%$. While the remaining $31.8 \%$ can be explained by other variables not examined by this study. Simultaneous testing shows that the independent variables, namely Culture, Social, Personality, Psychology, jointly affect student decisions. This is indicated by the F Count of 61.517. From testing the research variables partially shows that the independent variables, namely Culture, Social, Personality, Psychology, have an effect on the dependent variable, namely Student Decisions. From the independent variables, namely Culture, Social, Personality, the most dominant variable is psychological. This is indicated by the lowest level of significance, namely $\alpha=0.000$ and the greatest coefficient, namely the $t$ value of 4.766 .

Keywords:

Culture, Social, Personality, Psychology, Student Decisions

\section{Preliminary}

The large number of private universities in the city of Surabaya and the large number of study programs causes competition between private universities and between study programs which is getting tighter. Private universities in the city of Surabaya compete to attract students who will continue their studies at higher education institutions. In order to win the competition, each study program in PTS is actively trying to improve its quality and quantity, starting from recruiting lecturers, working with domestic and foreign PTNs and PTS, completing facilities and actively promoting in various media. On the other hand, this competition indirectly provides benefits for students, because students have many choices to decide on study programs and universities which height to choose. Rational students will certainly choose quality study programs and private universities. 
International Journal of Economics, Business and Accounting Research (IJEBAR)

Peer Reviewed - International Journal

Vol-4, Issue-3, 2020 (IJEBAR)

E-ISSN: 2614-1280 P-ISSN 2622-4771

http://jurnal.stie-aas.ac.id/index.php/IJEBAR

Anticipating these facts, the student decision-making process in choosing a study program in a particular private university is very important to be known by managers of private universities through consumer behavior studies. Kotler and Keller (2012: 173) argue that consumer behavior is the study of how individuals, groups and organizations choose, buy, use, and how goods, services, ideas, or experiences satisfy their needs and desires. In making purchases, consumer behavior influenced by several factors including cultural, social, personality and psychological factors. Marketers must try to understand consumers, know what they need, what their tastes are and how they make decisions. Meanwhile, according to Setiadi (2003: 11) purchasing decisions are strongly influenced by 4 factors, namely: 1). Culture which includes: culture, sub culture, and social class. 2). Social, including: Reference group, family, role and status. 3). Personality, including: Age and stages in the life cycle, work, economic conditions, lifestyle, personality and self-concept. 4). Psychological, including: motivation, perception, learning process, beliefs and attitudes.

From the description above, the researcher is interested in examining the factors that influence students to choose a management study program. The factors that influence students in choosing management study programs and colleges that organize management study programs are very important for managers to know universities in order to determine what strategies the tertiary institutions should do to attract prospective students.

Formulation of the problem

This research problem is expressed in the form of the following questions:

- Does Culture, Social, Personality, Psychology simultaneously influence the student's decision to choose a Management study program at the Faculty of Economics and Business, University of Dr. Soetomo Surabaya?

- Does Culture, Social, Personality, Psychology partially influence the student's decision to choose the Management study program at the Faculty of Economics and Business, Dr. Soetomo University, Surabaya?

Purpose of the Problem

- To test and analyze whether Culture, Social, Personality, Psychology simultaneously influence the student's decision to choose a Management study program at the Faculty of Economics and Business, Dr. Soetomo Surabaya

- To test and analyze whether culture, social, personality, psychology partially influence the student's decision to choose a management study program at the Faculty of Economics and Business, Dr. Soetomo University, Surabaya.

\section{Theoretical and Hypothesis Review}

\subsection{Consumer Behavior}

The study of consumer behavior is important in marketing management. Marketers must understand consumer behavior so that they are able to market their products well, can design appropriate marketing strategies, and can have better competitive abilities.

According to Engel et al., (2006) in (Sangadji, 2013: 7) consumer behavior is an action that is directly involved in obtaining, consuming, and ending products / services, including the processes that precede and follow these actions. Meanwhile, according to Sumarwan (2003: 26) consumer behavior is all activities, actions, and psychological processes that drive these actions before buying, when buying, using, spending products and services after evaluating activities.

\subsection{Culture}

Culture is all values, thoughts, symbols that affect the behavior, attitudes, beliefs and habits of a person and society (Sumarwan, 2003: 170). Culture is not only abstract, such as values, thoughts and beliefs, culture can be in the form of material objects called cultural artifacts. Culture will provide guidance to someone about acceptable behavior by a society, and culture will also give a sense of identity to someone in a society. 
International Journal of Economics, Business and Accounting Research (IJEBAR)

Peer Reviewed - International Journal

Vol-4, Issue-3, 2020 (IJEBAR)

E-ISSN: 2614-1280 P-ISSN 2622-4771

http://jurnal.stie-aas.ac.id/index.php/IJEBAR

Cultural factors that influence consumer behavior, according to Kotler (2005: 203), "cultural factors have a broad and deep influence on purchasing behavior, these cultural factors include; culture, sub-culture, and social class".

\section{Culture}

Kotler (2005: 203) says, "culture is the determinant of the most basic desires and behaviors". Culture begins with habits. Culture is a way of life that is developed and shared by a group of people and is passed down from generation to generation. Culture is made up of many complex elements, including religious and political systems, customs, language, tools, clothing, buildings and works of art.

\section{Sub-culture}

Each culture consists of smaller sub-cultures which provide more special characteristics and socialization for its members. Sub-culture consists of nationality, religion, racial group and geographic area. When subcultures become large and affluent enough, companies often design marketing programs specifically to serve them. Many sub-cultures make up important market segments, and marketers often design products and marketing programs tailored to their needs.

\section{Social class}

Basically, all societies have social strata. The stratification sometimes takes the form of a caste system where members of different castes are raised with certain roles and cannot change their caste membership. Stratification is more often found in the form of social class. According to Kotler (2005: 203), social class is "a relatively homogeneous and permanent division of society, which is arranged hierarchically and whose members share similar values, interests, and behaviors".

According to Sumarwan (2003: 171), cultural elements include:

Value

Value is belief or everything that is considered important by a person or a society. Value can mean a belief about something, but value is not just a belief. Values direct a person to behave according to his culture.

Norms

Norms are societal rules about good and bad attitudes, what they can and shouldn't. Norms will direct a person about acceptable and unacceptable behavior.

Habits

Habits are various forms of behavior and actions that are culturally accepted. This habit is passed down from generation to generation from generation to generation.

Myth

Myth describes a story or belief that contains values and idealism for a society. Myths are often very difficult to prove.

Symbol

Symbol is anything (object, name, color, concept) that has other important meaning (the desired cultural meaning).

\subsection{Social}

According to Lamb (2001) in Koesoemaningsih (2013) social factors are a group of people who both closely consider equality in community status or respect who continually socialize among themselves both formally and informally.

According to Setiadi (2003: 12), a consumer's behavior is also influenced by social factors such as: reference group, family, and the role and status of consumers, these factors influence consumer responses.

\section{Reference Group}

Reference groups are all groups that have a direct or indirect influence on a person's attitude or behavior. Groups that have direct influence on a person are called membership groups. Some membership groups are primary groups, such as family, friends, neighbors and co-workers, who interact with a person on an ongoing and informal basis. People also belong to secondary groups, such 
International Journal of Economics, Business and Accounting Research (IJEBAR)

Peer Reviewed - International Journal

Vol-4, Issue-3, 2020 (IJEBAR)

E-ISSN: 2614-1280 P-ISSN 2622-4771

http://jurnal.stie-aas.ac.id/index.php/IJEBAR

as denominations, professionals and trade associations which tend to be more formal and require less routine interaction.

Family

The family is the most important consumer purchasing organization in society, and it has been the object of extensive research. Family members are the most influential primary reference group. We can distinguish between two families in the life of the buyer. The family is the most important consumer purchasing organization in society and it has been the object of extensive research. Family members are the most influential primary reference group.

Role and Status

The position of a person in a group can be determined in terms of role and status. Each role carries a status that reflects the general respect by society.

\subsection{Personality}

According to Suryani (2013: 47), personality is seen as a characteristic that exists in an individual that involves various psychological processes, which will determine a person's tendencies and responses to the environment. The personality is consistent and lasts a long time. It is very important for marketers to explain and predict consumer behavior in terms of their personality.

According to Kotler (2017: 222), consumer decisions are influenced by personal characteristics. These characteristics include; age and stage of the life cycle, occupation, economic situation, lifestyle, and the personality and self-concept of the buyer.

Age and Life Cycle Stage

Everyone buys different goods and services throughout their life. They eat baby food in the early days of life, eat a variety of foods during the growth period to adulthood, and special diets at certain times. Appetite for clothing, entertainment, and other items is also related to age.

Employment and the Economic Environment

A person's job and economic conditions affect his consumption patterns. What is meant by a person's economic condition consists of income that can be spent (level, stability and pattern), savings and assets.

Lifestyle

People from the same sub-culture, social class, and occupation can have different lifestyles. Lifestyle is a person's lifestyle in the world that is revealed in their activities, interests, and opinions. Lifestyle describes the whole person who interacts with the environment.

Personality and Self Concept

Each person has a different personality that affects their buying behavior. Personality is a distinguished trait of human psychology that produces relatively consistent and long-lasting responses to the stimuli of his environment

\subsection{Psychological}

Psychology is a science that studies human behavior in relation to its environment. Based on language, psychology consists of two words that come from Greek, psyche (soul) and logos (science). So psychology is the science of the soul. According to Lamb (2001) in Koesoemaningsih (2013), psychological factors are a way of recognizing their feelings, collecting and analyzing information, formulating thoughts and opinions and taking action.

According to Kotler (2005: 215), a person's purchase choices are influenced by four main psychological factors, namely motivation, perception, learning, and beliefs and attitudes.

Motivation

According to J. Moscowits, in Setiadi (2003: 94) motivation is defined as the initiation and direction of behavior and motivation lessons are actually behavioral lessons. Motivation can be defined as a driving force that creates someone's excitement so that they are willing to cooperate, work effectively and are integrated with all their efforts to achieve satisfaction.

Perception 
International Journal of Economics, Business and Accounting Research (IJEBAR)

Peer Reviewed - International Journal

Vol-4, Issue-3, 2020 (IJEBAR)

E-ISSN: 2614-1280 P-ISSN 2622-4771

http://jurnal.stie-aas.ac.id/index.php/IJEBAR

A person who is motivated is ready to act. How a person who is motivated to act will be influenced by his perception of certain situations. According to Kotler (2005: 216) perception is a process used by an individual to choose to organize and interpret inputs, information to create a meaningful picture of the world. Everyone's perception of an object will be different

\section{Learning}

According to Assael (1992) in Setiadi (2003: 185), consumer learning is a change in behavior that occurs as a result of past experiences. Consumers gain various experiences in purchasing products and what product brands they like. Consumers will adjust their behavior with past experiences.

\section{Beliefs and Attitudes}

Through acting and learning, one gains confidence and attitude. Both then influence their buying behavior. According to Kotler (2005: 218), belief is a description of one's thoughts regarding the image of something. People's beliefs about a product or brand influence their purchasing decisions. Meanwhile, according to Kotler (2005: 219) attitude is an evaluation, emotional feelings, and a tendency for actions that are beneficial or not beneficial and last a long time for a person towards certain objects or ideas.

Consumer Decisions

Kotler (2005: 42) suggests that decision making is an individual activity that is directly involved in obtaining and using the goods offered. According to Kotler (2017: 235) before deciding to purchase goods or services, consumers usually go through 5 stages, namely

1. Introduction of the problem. The buying process begins when the buyer recognizes a problem or need. The recognition of this need is intended to identify unfulfilled and unfulfilled needs and wants

2. Information search. Someone who is moved by the stimulus will try to find more information which is involved in the search for needs.

3. Alternative evaluation is a process in which an alternative choice is adjusted and selected to meet consumer needs. How consumers evaluate alternative goods to be purchased depends on each individual and the specific buying situation.

4. The buying decision is a process in real buying. So, after the steps above are carried out, consumers must make a decision whether to buy or not.

Behavior after purchase. The marketer's job does not end when the product is purchased, but continues into the post-purchase period. After a product purchase occurs, consumers will experience a level of satisfaction or dissatisfaction

\section{Hypothesis}

1. It is suspected that Culture, Social, Personality, Psychology simultaneously influence the student's decision to choose a Management study program at the Faculty of Economics and Business, Dr. Soetomo University, Surabaya.

2. It is suspected that culture, social, personality, psychology partially influence the student's decision to choose the Management study program at the Faculty of Economics and Business, Dr. Soetomo University, Surabaya.

\section{Research Methods}

\section{Types of research}

This research is an explanatory research, namely research that explains the causal relationship between several variables through hypothesis testing. Where this relationship can be through a correlation or interrelated relationship, or to find out the contribution of one variable to another. In this study, this study explains the influence of cultural, social, personality, and psychological variables on student decisions.

\section{Population, Sample, and Sampling Technique}

The population in this study were S1 class 2017 students who were active in the odd semester 2017/2018 management study program at the Faculty of Economics and Business, University of Dr. Soetomo Surabaya with 170 students.

Meanwhile, to calculate the sample, the Slovin formula is used as follows: 
International Journal of Economics, Business and Accounting Research (IJEBAR)

Peer Reviewed - International Journal

Vol-4, Issue-3, 2020 (IJEBAR)

E-ISSN: 2614-1280 P-ISSN 2622-4771

http://jurnal.stie-aas.ac.id/index.php/IJEBAR

$\mathrm{n}=\mathrm{N} /\left(1+\mathrm{N}\left(\mathrm{e}^{\wedge} 2\right)\right)$

Where :

$\mathrm{n}=$ Number of Samples

$\mathrm{N}=$ Population

$\mathrm{e}=$ Error Tolerance Limit (Error) is 5\%

$$
\begin{gathered}
n=\frac{170}{1+170\left(0,05^{2}\right)} \\
n=\frac{170}{1+170(0,0025)} \\
n=\frac{170}{1+0,425} \\
n=\frac{170}{1,425} \\
n=120
\end{gathered}
$$

Thus the research sample used in the study was 120 undergraduate students class 2017 management study program at the Faculty of Economics and Business, University of Dr. Soetomo, Surabaya. The sampling was determined by accidental sampling.

\section{Data Retrieval Technique}

The data collection technique in this study was carried out by distributing questionnaires and measuring the scale of the research questionnaire using a Likert scale.

Operational Definition of Variables

The variables used in this study: The dependent variable is student decision $(\mathrm{Y})$ and the independent variable (X), which consists of: 1. Culture (X1). 2. Social (X2). 3. Personality (X3). 4. Psychological (X4)

1. Culture (X1)

It is a student action to choose a management study program based on the beliefs, habits, thoughts, feelings that a student has from generation to generation, or from generation to generation. Furthermore, cultural variables are measured through indicators (Sumarwan, 2003: 171):

a. Good and bad views (X1.1)

b. Hearing habits (X1.2)

c. Assessment of quality (X1.3)

2. Social (X2)

Is a group of people such as friends, family, and students' social status in society, who influence students in choosing management study programs. Social factors are measured through indicators (Setiadi, 2003: 12).

a. Friend presence (X2.1)

Is the existence of friends who can influence students in choosing a management study program.

b. Existence of family (X2.2)

Is the existence of parents or siblings who can influence students in choosing a management study program.

c. Social status in society (X2.3)

Is the social position of students in a group in society.

3. Personality (X3)

Personality is the nature and habit patterns of students, which are influenced by their immediate environment, to choose a management study program which is then expressed in an act of deciding which management study program they choose. Personality factors are measured through indicators (Kotler, 2017: 222)

a. Parents' occupation (X3.1)

It is an activity for parents of students to make ends meet.

b. Lifestyle (X3.2)

It is a student habit pattern in living their daily life. 
International Journal of Economics, Business and Accounting Research (IJEBAR)

Peer Reviewed - International Journal

Vol-4, Issue-3, 2020 (IJEBAR)

E-ISSN: 2614-1280 P-ISSN 2622-4771

http://jurnal.stie-aas.ac.id/index.php/IJEBAR

c. The state of the economy (X3.3)

Is the ability of students to pay for their studies.

4. Psychological (X4)

It is the motivation or motivation from within students that influences their decision to choose a management study program. Psychological factors are measured through indicators (Kotler 2005: 215)

a. Motivation (X4.1)

Is the driving force for a change in a student that appears in psychological symptoms, feelings, and emotions, thus encouraging the student to choose a management study program.

b. Perception (X4.2)

Is the process of selecting, organizing, and interpreting information from a student about a management study program.

c. Knowledge or learning (X4.3)

Is a change in a student's behavior that comes from experience.

5. Student Decision (Y)

It is a student process to assess and then choose from a variety of alternative study programs, according to their importance by determining a choice of a particular management study program that is considered the best. Student decision factors are measured through indicators (Kotler, 2017: 235)

a. Introduction of needs (Y1)

Is the identification of the needs and desires of a student that have not been met from the management study program.

b. Information search (Y2)

Is the collection of various information for a student about the management study program to meet his needs.

c. Alternative Evaluation (Y3)

Is the process of assessing several alternative study programs according to the needs of a student.

d. Disconnect (Y4)

Is the process of a student in selecting a real management study program.

\section{Data Analysis Techniques}

The stages of analysis in this research are:

1. Validity and Reliability Test

a. Validity test

Validity is a degree of accuracy in measuring research tools regarding the actual content being measured. The analysis aims to test whether each question item is valid. According to Sugiyono (2016: 134) states that if the correlation coefficient is equal to 0.3 or more (at least 0.3 ), then the instrument item is stated valid.

b. Reliability Test

A reliable instrument is an instrument that, when used several times to measure the same object, will produce the same data. The reliability of the variable is determined based on the Cronbach alpha value, if the alpha value is greater than 0.6, it is said that the variable is reliable or reliable. To simplify the analysis, the SPSS data processing application is used.

2. Classic Assumption Test

3. Multiple Linear Regression Analysis

Multiple linear regression analysis is used to measure the presence or absence of influence between cultural (X1), social (X2), personality (X3), psychological (X4) factors as independent variables (free) on student decisions ( $\mathrm{Y})$ as dependent variables (dependent) .

The regression equation for the six predictors (Sugiyono, 2007: 275) is as follows:

$\mathrm{Y}=\mathrm{a}+\mathrm{b} 1 \mathrm{X} 1+\mathrm{b} 2 \mathrm{X} 2+\mathrm{b} 3 \mathrm{X} 3+\mathrm{b} 4 \mathrm{X} 4+\mathrm{e}$

Where :

$\mathrm{Y}=$ Student decision 
International Journal of Economics, Business and Accounting Research (IJEBAR)

Peer Reviewed - International Journal

Vol-4, Issue-3, 2020 (IJEBAR)

E-ISSN: 2614-1280 P-ISSN 2622-4771

http://jurnal.stie-aas.ac.id/index.php/IJEBAR

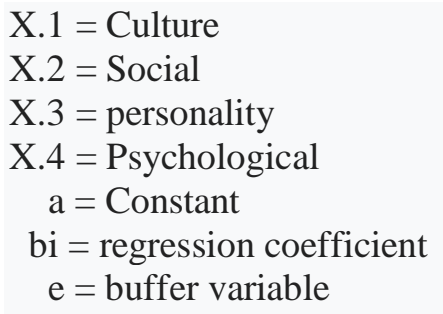

4.Multiple Determination Coefficient (R2)

5. Hypothesis Testing

a. Simultaneous influence testing with the $\mathrm{F}$ test

he $\mathrm{F}$ test was conducted to test the significance of the simultaneous influence between culture (X1), social (X2), personality (X3), psychology (X4) on student decisions (Y) with a degree of error of $5 \%$.

b. Partial effect testing with $t$ test

The $t$ test was conducted to test the significance of the partial influence between culture (X1), social (X2), personality (X3), psychological (X4) on student decisions (Y).

\section{Research Results and Discussion}

\section{Research Result}

1. Validity Test

The validity test was carried out to test the results of the distribution of the questionnaire to respondents who stated that they were appropriate or valid for the statement items that were compiled as indicators of research variables. Following are the results of validity testing by calculating the Pearson Product Moment correlation coefficient:

Table 1

Validity test

\begin{tabular}{|c|c|c|c|}
\hline Variable & Statement & Korelations Sig & Conclusion \\
\hline \multirow{3}{*}{ Culture $\left(\mathrm{X}_{1}\right)$} & $\mathrm{X}_{1 \cdot 1}$ & 0,783 & Valid \\
\hline & $\mathrm{X}_{1.2}$ & 0,787 & Valid \\
\hline & $\mathrm{X}_{1 \cdot 3}$ & 0,711 & Valid \\
\hline \multirow{3}{*}{$\begin{array}{l}\text { Social } \\
\left(\mathrm{X}_{2}\right)\end{array}$} & $\mathrm{X}_{2 \cdot 1}$ & 0.823 & Valid \\
\hline & $X_{2 \cdot 2}$ & 0,757 & Valid \\
\hline & $\mathrm{X}_{2 \cdot 3}$ & 0,667 & Valid \\
\hline \multirow{5}{*}{$\begin{array}{l}\text { Personality } \\
\left(X_{3}\right)\end{array}$} & $X_{3.1}$ & 0,682 & Valid \\
\hline & $\mathrm{X}_{3.2}$ & 0,698 & Valid \\
\hline & $X_{3.3}$ & 0,782 & Valid \\
\hline & $\mathrm{X}_{3.4}$ & 0,751 & Valid \\
\hline & $\mathrm{X}_{3.5}$ & 0,691 & Valid \\
\hline \multirow{4}{*}{$\begin{array}{l}\text { Psychological } \\
\left(\mathrm{X}_{4}\right)\end{array}$} & $\mathrm{X}_{4.1}$ & 0,834 & Valid \\
\hline & $\mathrm{X}_{4.2}$ & 0,731 & Valid \\
\hline & $\mathrm{X}_{4.3}$ & 0,799 & Valid \\
\hline & $X_{4.4}$ & 0,746 & Valid \\
\hline \multirow{3}{*}{$\begin{array}{l}\text { Student } \\
\text { Decision } \\
\left(\mathrm{Y}_{2}\right)\end{array}$} & $Y_{2.1}$ & 0,626 & Valid \\
\hline & $\mathrm{Y}_{2.2}$ & 0,827 & Valid \\
\hline & $\mathrm{Y}_{2.3}$ & 0,894 & Valid \\
\hline
\end{tabular}


International Journal of Economics, Business and Accounting Research (IJEBAR)

Peer Reviewed - International Journal

Vol-4, Issue-3, 2020 (IJEBAR)

E-ISSN: 2614-1280 P-ISSN 2622-4771

http://jurnal.stie-aas.ac.id/index.php/IJEBAR

\begin{tabular}{|l|l|l|l||}
\hline Variable & Statement & Korelations Sig & Conclusion \\
\hline & $Y_{2.4}$ & 0,637 & Valid \\
\hline
\end{tabular}

Based on Table 1 above shows that the results of testing the validity of the indicators of all independent and dependent variables are valid, because the correlation coefficient (rcount) $\geq 0.3$ between the item score and the total score.

2 Reliability Test

Reliability test is used to determine the reliability or consistency of the instrument (questionnaire) used. The following are the results of reliability testing:

Table 2

Reliability Test

\begin{tabular}{|l|l|l|l|}
\hline Variabel & $\begin{array}{l}\text { Cronbach } \\
\text { Alpha }\end{array}$ & $\begin{array}{l}\text { Nilai } \\
\text { Kritis }\end{array}$ & Kesimpulan \\
\hline Culture $\left(\mathrm{X}_{1}\right)$ & 0,624 & 0.6 & Reliabel \\
\hline Social $\left(\mathrm{X}_{2}\right)$ & 0,610 & 0.6 & Reliabel \\
\hline Personality $\left(\mathrm{X}_{3}\right)$ & 0,766 & 0.6 & Reliabel \\
\hline Psikologis $\left(\mathrm{X}_{4}\right)$ & 0,782 & 0.6 & Reliabel \\
\hline Student Decision $\left(\mathrm{Y}_{1}\right)$ & 0,744 & 0.6 & Reliabel \\
\hline
\end{tabular}

Based on Table 2, it can be seen that these variables are reliable, because all alpha values are> 0.6. This means that all questionnaires for each variable are reliable. Thus, the questionnaire for all variables is reliable to measure each variable.

Classic Assumption Testing

a. Multicollinearity test

Multicollinearity is a linear relationship between independent variables. The existence of multicollinearity can be done by looking at the Variance Inflation Factor (VIF). If VIF <10, multicollinearity does not occur.

Table 3

Multicollinearity test

\begin{tabular}{|l|c|c|}
\hline \multicolumn{1}{|c|}{ Variable } & \multicolumn{2}{|c|}{ collinearity Statistics } \\
\hline Culture $\left(\mathrm{X}_{1}\right)$ & Toletance & VIF \\
\hline Social $\left(\mathrm{X}_{2}\right)$ & 0,41 & 2,439 \\
\hline Personality $\left(\mathrm{X}_{3}\right)$ & 0.995 & 1,005 \\
\hline Psikologis $\left(\mathrm{X}_{4}\right)$ & 0,449 & 2,226 \\
\hline Student Decision $\left(\mathrm{Y}_{1}\right)$ & 0,455 & 2.200 \\
\hline
\end{tabular}

From table 3 it appears that the VIF value is below 10, it can be said that there is no multicollinearity. b.Heteroscedasticity Test

Heteroscedasticity means that variable variations are not the same for all observations. The way to determine the symptoms of heteroscedasticity is by using the graph method. If there is no certain pattern (wavy, widened, then narrowed) and the dots spread above and below the 0 on the $\mathrm{Y}$ axis, heteroscedasticity will not occur.

The following is the detection of heteroscedasticity using a scatterplot chart 
International Journal of Economics, Business and Accounting Research (IJEBAR)

Peer Reviewed - International Journal

Vol-4, Issue-3, 2020 (IJEBAR)

E-ISSN: 2614-1280 P-ISSN 2622-4771

http://jurnal.stie-aas.ac.id/index.php/IJEBAR

Picture 1

Heteroscedasticity Test

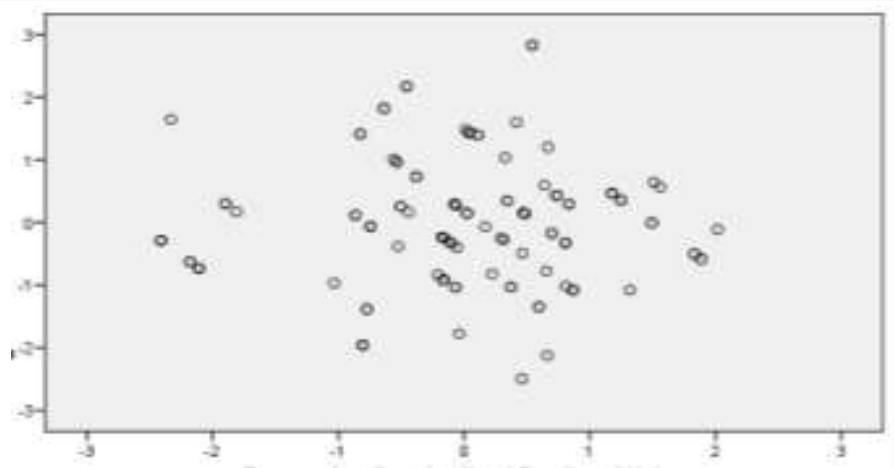

From Figure 1, it is known that the point spreads randomly either above or below the zero on the $\mathrm{Y}$ axis, there is no clear pattern. Hence, heteroscedasticity does not occur.

\section{Multiple Linear Regression Analysis}

The analysis in this study uses the independent variable $(\mathrm{X})$ which consists of four independent variables, namely, the variable X1 (Culture), X2 (Social), X3 (Personality), X4 (Psychological), while the dependent variable (Y) is the Student Decision.

To find out how much influence the independent variables X1 (Culture), X2 (Social), X3 (Personality), X4 (Psychology), on the dependent variable Y (Student Decision), it can be calculated using multiple linear regression analysis techniques. Based on the calculation results of the multiple linear regression model, the results of the regression equation are obtained which can be seen in table 4 below.

Table 4

Regression Analysis

\begin{tabular}{|c|c|c|c|c|c|c|c|c|}
\hline & \multicolumn{2}{|c|}{$\begin{array}{l}\text { unstandardized } \\
\text { Coefficients }\end{array}$} & \multirow{2}{*}{$\begin{array}{l}\text { Standardized } \\
\text { Coefficients } \\
\text { Beta }\end{array}$} & \multirow[b]{2}{*}{$\mathrm{T}$} & \multirow[b]{2}{*}{ sig } & \multicolumn{3}{|c|}{ Correlations } \\
\hline & B & $\begin{array}{l}\text { Std } \\
\text { Error }\end{array}$ & & & & $\begin{array}{l}\text { Zer0- } \\
\text { order }\end{array}$ & Partial & part \\
\hline Constant & 0.484 & 0,231 & & 2,096 & 0,038 & & & \\
\hline & 0.259 & 0,075 & 0,285 & 3,473 & 0.001 & 0,731 & 0,308 & 0,183 \\
\hline & 0,88 & 0,043 & 0,108 & 2,038 & 0,044 & 0,111 & 0,187 & 0,107 \\
\hline & 0,24 & 0,072 & 0,261 & 3,325 & 0,001 & 0,709 & 0,296 & 0,175 \\
\hline & 0,32 & 0,067 & 0,372 & 4,766 & 0,000 & 0,741 & 0,406 & 0,251 \\
\hline
\end{tabular}

From table 4 it can be seen that the resulting regression equation is as follows:

$Y=0,484+0,259 X_{1}+0,088 X_{2}+0,240 X_{3}+0,320 X_{4}$

he test results from Coeffiens, can be concluded as follows:

1. The value of the dependent variable (Y) Student's decision can be seen from its constant value of 0.484 , provided that the independent variable consisting of the independent variables $\mathrm{X} 1$ (Cultural), X2 (Social), X3 (Personality), X4 (Psychological), is constant. (fixed), the value of Student Decisions is 0.484 units.

2. The value of $\mathrm{b} 1$ is 0.259 . This shows that if the social, personality and psychological values are constant while Culture (X1) increases by $1 \%$, it will increase Student Decision (Y) by 0.259 units. The coefficient is positive, meaning that there is a positive relationship between culture (X1) and student decisions. The more the value of culture (X1) increases, the student's decision (Y). 
International Journal of Economics, Business and Accounting Research (IJEBAR)

Peer Reviewed - International Journal

Vol-4, Issue-3, 2020 (IJEBAR)

E-ISSN: 2614-1280 P-ISSN 2622-4771

http://jurnal.stie-aas.ac.id/index.php/IJEBAR

3. The b2 value is 0.088 . This shows that if the cultural, personality and psychological values are constant, while Social (X2) increases by $1 \%$, it will increase Student Decision (Y) by 0.088 units. The coefficient is positive, meaning that there is a positive relationship between Social (X2) and Student Decisions. The more the value of Social (X2) increases the Student Decision (Y).

4. The value of $b 3$ is 0.240

It shows that if the cultural, social, and psychological values are constant while Personality (X3) increases by $1 \%$, it will increase Student Decision (Y) by 0.240 units. A positive coefficient means that there is a positive relationship between Personality (X3) and Student Decisions. The more the value of Personality (X3) increases the Student Decision (Y).

5. The value of b4 is 0.320

This shows that if the cultural, social, and personality values are fixed while the Psychological (X4) increases by $1 \%$, it will increase Student Decision (Y) by 0.320 units. The coefficient is positive, meaning that there is a positive relationship between Psychology (X4) and Student Decisions. The more the value of Psychology (X4) increases the Student Decision (Y).

\section{Determination Coefficient Test $\left(\mathbf{R}^{2}\right)$}

Testing the coefficient of determination (R2) is used to measure the proportion or percentage of the model's ability to explain the dependent variable. The coefficient of determination ranges from zero to one $\left(0 \leq R^{2} \geq 1\right)$. If $R^{2}$ is greater (close to one), it can be said that the influence of the independent variable $(\mathrm{X})$ is large on the dependent variable $(\mathrm{Y})$. This is meaningful

the model used is stronger to explain the effect of the independent variables on the dependent variable and vice versa.

Table 5

Result of the coefficient of determination

\begin{tabular}{|c|l|l|l|}
\hline R & $\begin{array}{l}\text { R } \\
\text { Sguare }\end{array}$ & Adjusted & Std.Error 0f \\
\hline & & R Square & the estimate \\
\hline 0,826 & 0,682 & 0,67 & 0,38221 \\
\hline
\end{tabular}

Based on Table 5, it can be seen that: R Square of 0.682 means that the Student Decision variable can be influenced by the Cultural, Social, Personality and Psychological variables of $68.2 \%$. While the remaining $31.8 \%$ can be influenced by other variables not examined by this study.

Simultaneous Test (Test F)

This test is done to see whether all the independent variables included in the model have a joint influence on the dependent variable. Table 6 below is the F test:

Table 6

F Test Results

\begin{tabular}{|c|c|c|c|c|c|}
\hline & Sum of & $\mathrm{df}$ & $\begin{array}{l}\text { Mean } \\
\text { Square }\end{array}$ & $\mathrm{F}$ & Sig \\
\hline & Squares & & & & \\
\hline Regression & 35,946 & 4 & 8,986 & 61,517 & 0,000 \\
\hline Residual & 16,799 & 115 & 0,145 & & \\
\hline Total & 52,745 & 119 & & & \\
\hline
\end{tabular}

In Table 6, it can be seen that the value of Fcount $=61.517$ with a significance level $=0.000<0.05$ so that Ho rejects and accepts Ha. Based on the criteria for testing the hypothesis if the level of significance is $<0.05$, it indicates that the independent variables, namely Culture, Social, Personality, and Psychology, jointly influence student decisions.

Partial Test (t test)

This test is conducted to determine how far the influence of an independent variable partially (individually) on the dependent variable. Here are the test output results 
International Journal of Economics, Business and Accounting Research (IJEBAR)

Peer Reviewed - International Journal

Vol-4, Issue-3, 2020 (IJEBAR)

E-ISSN: 2614-1280 P-ISSN 2622-4771

http://jurnal.stie-aas.ac.id/index.php/IJEBAR

Table 7

t Test Results

\begin{tabular}{|c|c|c|c|c|c|c|c|c|}
\hline & \multicolumn{2}{|c|}{$\begin{array}{l}\text { unstandardized } \\
\text { Coefficients }\end{array}$} & \multirow{2}{*}{$\begin{array}{l}\text { Standardized } \\
\text { Coefficients } \\
\text { Beta }\end{array}$} & \multirow[b]{2}{*}{$\mathrm{t}$} & \multirow[b]{2}{*}{ sig } & \multicolumn{3}{|c|}{ Correlations } \\
\hline & B & \begin{tabular}{|l|} 
Std \\
Error \\
\end{tabular} & & & & $\begin{array}{l}\text { Zer0- } \\
\text { order }\end{array}$ & Partial & Part \\
\hline Constant & 0.484 & 0,231 & & 2,096 & 0,038 & & & \\
\hline & 0.259 & 0,075 & 0,285 & 3,473 & 0.001 & 0,731 & 0,308 & 0,183 \\
\hline & 0,88 & 0,043 & 0,108 & 2,038 & 0,044 & 0,111 & 0,187 & 0,107 \\
\hline & 0,24 & 0,072 & 0,261 & 3,325 & 0,001 & 0,709 & 0,296 & 0,175 \\
\hline & 0,32 & 0,067 & 0,372 & 4,766 & 0,000 & 0,741 & 0,406 & 0,251 \\
\hline
\end{tabular}

The results from Table 7 are as follows:

1. Cultural Variables (X1) with $\alpha=0.01$. Because the value of $\alpha<0.05$, it can be concluded that the Cultural variable partially affects Student Decisions.

2. Social variables (X2) with $\alpha=0.044$. Because the value of $\alpha<0.05$, it can be concluded that social variables partially affect student decisions.

3. Personality variable (X3) with $\alpha=0.001$. Because the value of $\alpha<0.05$, it can be concluded that the Personality variable partially affects Student Decisions.

4. Psychological variables (X4) with $\alpha=0.000$. Because the value of $\alpha<0.05$, it can be concluded that the psychological variables partially affect student decisions.

5. Whereas the highest $t$ value among the independent variables is the psychological variable, namely 4.766. And all the probabilities on the independent variable are significant at the 5\% level and those at the lowest significance are psychological variables, namely $\alpha=0.000$. That from the independent variables, namely Culture, Social, Personality, Psychology

the most dominant is the Psychological variable. This is indicated by the lowest level of significance and the greatest coefficient.

\section{Discussion}

In this study, through multiple linear regression the formula $\mathrm{Y}=0.484+0.259 \mathrm{X} 1+0.088 \mathrm{X} 2+$ $0.240 \mathrm{X} 3+0.320 \mathrm{X} 4$ is obtained. The constant is positive, meaning that it shows the positive influence of the independent variable. If the independent variable increases by one unit, the dependent variable will increase or be fulfilled. The value of all coefficients is also positive, which means that there is a positive relationship between the independent variable and the dependent variable.

The R Square coefficient of 0.682 means that the variation of student decisions can be explained by the cultural, social, personality and psychological variables of $68.2 \%$. While the remaining $31.8 \%$ can be explained by other variables not examined by this study.

Simultaneous testing shows that the independent variables, namely Culture, Social, Personality, Psychology, jointly affect student decisions. This is indicated by the F Count of 61.517.

From testing the research variables partially shows that the independent variables, namely Culture, Social, Personality, Psychology, have an effect on the dependent variable, namely Student Decisions.

Of the independent variables, namely Culture, Social, Personality, Psychology, the most dominant is the Psychological variable. This is indicated by the lowest level of significance, namely $\alpha=0.000$ and the greatest coefficient, namely the $t$ value of 4.766 .

For the Cultural variable (X1), it is known that the significance value is 0.001 . The results of this study support the results of previous studies conducted by Mulyati (2016) and Sitohang. The results of his research state that culture has a significant influence on consumer decisions.

For the social variable (X2), it is known that the significance value is 0.044 . The results of this study support the results of previous studies conducted by Mariaji and Yuniati (2014). The results of his 
International Journal of Economics, Business and Accounting Research (IJEBAR)

Peer Reviewed - International Journal

Vol-4, Issue-3, 2020 (IJEBAR)

E-ISSN: 2614-1280 P-ISSN 2622-4771

http://jurnal.stie-aas.ac.id/index.php/IJEBAR

research state that social has a significant influence on consumer decisions. These results do not support the results of previous research conducted by Sitohang (2013) which revealed that social factors have no significant effect on consumer

For the Personality variable (X3), it is known that the significance value is 0.001 . The results of this study support the results of previous studies conducted by Mariaji and Yuniati (2014). The results of his research state that personality has a significant influence on consumer decisions. These results do not support the results of previous research conducted by Sitohang (2013) which revealed that personality factors have no significant effect on consumer decisions.

For the Psychological variable (X4), it is known that the significance value is 0.000 . The results of this study support the results of previous studies conducted by Mariaji and Yuniati (2014), and Sitohang (2013). The results of his research state that psychology has a significant influence on consumer decisions

\section{Conclusions and Recommendations Conclusion}

Based on the results of the analysis it can be concluded as follows:

1. It is known that the regression formula is the formula $\mathrm{Y}=0.484+0.259 \mathrm{X} 1+0.088 \mathrm{X} 2+0.240 \mathrm{X} 3+$ $0.320 \mathrm{X} 4$. From this formula, it is known that the constant value is positive, meaning that it shows the positive influence of the independent variables, namely Culture (X1), Social (X2), Personality (X3) and Psychology (X4). The formula shows that all coefficients are positive, which means that there is a positive relationship between the independent variable and the dependent variable.

2. The R Square coefficient of 0.682 means that the variation of student decisions can be explained by the cultural, social, personality and psychological variables of $68.2 \%$. While the remaining $31.8 \%$ can be explained by other variables not examined by this study.

3. Simultaneous testing shows that the independent variables, namely Culture, Social, Personality, Psychology, jointly affect student decisions. This is indicated by the F Count of 61.517.

4 From testing the research variables partially shows that the independent variables, namely culture, social, personality, psychology, have an effect on the dependent variable, namely student decisions.

5. Of the independent variables, namely Culture, Social, Personality, Psychology, the most dominant is the Psychological variable. This is indicated by the lowest level of significance, namely $\alpha=0.000$ and the greatest coefficient, namely the t value of 4.766. Suggestion Based on the overall research results and the conclusions obtained, several suggestions can be developed for interested parties in this research. The suggestions put forward are as follows: 1. Faculty of Economics and Business Dr. Soetomo should pay more attention to and improve the factors that become the basis for student decisions in choosing study programs. 2. For further research, it is hoped that other independent variables can be used which are thought to affect the size of the student's trust and decisions so that more complete information will be obtained on the factors that can positively affect the trustworthiness of students' decisions. 3. That the Faculty of Economics and Business should pay more attention to the psychological factors of students in choosing a management study program, because this factor is the most dominant. 4. Promotional policies carried out by the Faculty of Economics and Business are more directed at a student approach to motivating and encouraging them to choose a management study program. In addition, it also provides sufficient knowledge about management study programs to students.

\section{References}

Anoraga, P. 2005. Manajemen Bisnis. Cetakan Ketiga. Rineka Cipta Jakarta.

Barkhi,R dan L.Wallace.2007.The impact of personality type on purchasing decisions in virtual stores. Inf Technol Manage 8:313-330.

Bilson, S. 2004. Panduan Riset Perilaku Konsumen. PT Gramedia Pustaka Utama. Jakarta.

Engel, J.F., R.D. Blackwel, dan P.W.Miniard. 2005. Consumer Behavior. Edisi kesepuluh. Jilid1. Binarupa Aksara . Jakarta. 
International Journal of Economics, Business and Accounting Research (IJEBAR)

Peer Reviewed - International Journal

Vol-4, Issue-3, 2020 (IJEBAR)

E-ISSN: 2614-1280 P-ISSN 2622-4771

http://jurnal.stie-aas.ac.id/index.php/IJEBAR

Indrawati,A.2014.Faktor-Faktor yang Dipertimbangkan Mahasiswa Dalam Memilih Lembaga Pendidikan dan Latihan Bisnis di Kota Malang.Jurnal Kompilek 6 (1) : 53-67

Kotler, P, dan G. Amstrong. 2001.Prinsiples of Marketing. Ninth Edition.Prentice Hall,Inc.New Jersey. Terjemahan A.Sindoro.2004.Dasar-Dasar Pemasaran. Edisi 9.PT Indeks. Jakarta

Koesoemaningsih,R.2013. Pengaruh Budaya, Sosial, Pribadi dan Psikologi Terhadap Keputusan Mahasiswa Dalam Memilih Pendidikan Pada Prodi Manajemen Fakultas Ekonomi Universitas Soerjo Ngawi. Media Soerjo 13( 2): 105 - 125

Kotler, P. 2005. Manajemen Pemasaran. Edisi kesembilan belas. Jilid-2. Indeks. Jakarta

Lamb, Charles W. (2001). Pemasaran. Edisi Pertama. Salemba Empat. Jakarta

Mulyati,Y, Mailinarti, dan Masruri. 2016. Analisis Faktor-Faktor Yang Mempengaruhi Keputusan Mahasiswa Dalam Memilih Perguruan Tinggi Swasta Di Kota Padang. Jurnal Ekonomi \& Bisnis Dharma Andalas 18( 1,): 45-65

Mowen, JC.dan M.Minor. 2001. Perilaku Konsumen. edisi 5. Jilid 2. Erlangga. Jakarta.

2002. Perilaku Konsumen. Erlangga.Jakarta

1995. Consumer behavior. International Edition. Prentice Hall, Inc, Englewood Cliffs. New Jersey

Mcknight, D.H., V. Choudury., \& C. J. Kacmar. 2002. Developing And Validating Trust Measure for E-Commerce: An Integrative Typology. Informatin System Research. 13(3): 334-359.

Mariajie W dan T.Yuniati.2014. Pengaruh Perilaku Konsumen Terhadap Keputusan Pembelian Compact Disc (CD) di Surabaya. Jurnal Ilmu \& Riset Manajemen. 3(8) : 1-15

Purwanti,E. 2015. Analisis Faktor-Faktor Pengambilan Keputusan Mahasiswa Memilih STIE "AMA" Salatiga.Jurnal Among Makarti 8 (16)

Setiadi, N. J. 2003. Prilaku Konsumen : Konsep dan Implikasinya untuk Strategi dan Penelitian Pemasaran. Edisi Pertama. Cetakan Pertama. Prenada Media. Jakarta.

Sumarwan, U. 2004. Perilaku Konsumen : Teori dan Penerapannya dalam Pemasaran.Cetakan Kedua. Ghalia Indonesia. Bogor.

Suryani,W dan P.Ginting. 2013. Faktor- Faktor yang Mempengaruhi Keputusan Mahasiswa Memilih Fakultas Ekonomi Universitas Islam Sumatra Utara Al Munawaroh Medan.Jurnal Modernisasi 9 (1)

Swastha, B dan H. Handoko. 2000. Manajemen Pemasaran : Analisa Perilaku Konsumen. Edisi I. BPFE Yogyakarta.

Sutisna, 2003. Perilaku Konsumen \& Komunikasi Pemasaran. Cetakan Kedua. Remaja Rosdakarya. Bandung.

Sugiyono. 2007. Metodologi penelitian Bisnis. Alfabeta . Bandung.

Sitohang, U. 2013. Pengaruh Budaya, Sosial, Pribadi, dan Psikologis Terhadap Keputusan Pengambilan Kredit di PT Bank Tabungan Pensiunan Nasional ,TBK. Tesis. Program Studi Magister Manajemen Program Pascasarjana Universitas Atma Jaya. Yogyakarta. 